\title{
The Formation of Electronics and IT Industry Clusters in Taiwan
}

\author{
Hsienyang Su*, Huimin Lu*, Tsuihsueh HwanG*, Chingjui LiU**, \\ Huichuan Cheng***, Hungfei $\mathrm{CHU}^{* * * *}$, Hitoshi HiRaKaWA**** \\ and Makoto TAWADA****
}

\begin{abstract}
Taiwan's hi-tech sector has grown rapidly; the expansion of the electronics and IT industry has been particularly impressive. Since the late 1970s, the electronics and IT industry has been positioned by the Taiwanese government as a key strategic industry the development of which should be prioritized, and today this industry is one of the most important contributors to the growth of the Taiwanese economy as a whole. Taiwan's hi-tech sector is mainly located in Northern Taiwan, where a major "hi-tech corridor" has emerged.

Besides examining how Taiwan's hi-tech sector has evolved over time, the present study also explores electronics and IT industry cluster development in Northern Taiwan. Using the results of a questionnaire survey on the industry cluster effect, inter-enterprise collaboration and technology innovation that was administered in late 2006, the study seeks to identify the salient characteristics of Taiwan's electronics and IT industry clusters. The study finds that active promotion of technology innovation is associated with enterprises that have been in existence for a relatively short time, those where the chairman or CEO has studied overseas, those where a high percentage of the company's shares are held by foreign investors, and those that are geographically close to their customers and suppliers. In addition, being located in an industry cluster, having a high percentage of shared held by foreign investors, and being located close to customers and suppliers are all associated with superior earnings performance.
\end{abstract}

JEL Classification : O31, O53

Keywords: Taiwan, Electronics and IT Industry, Industry Cluster, Inter-Enterprise Collaboration, Technology Innovation

\section{Introduction}

Innovation is closely linked to the clustering effect, which derives largely from the diffusion of knowledge. An empirical study by Audretsch and Fledman (1996) showed a positive correlation between the cost of knowledge transmission and the distance over which knowledge is transmitted; how far away sources of knowledge are is thus very important with respect to technology innovation. "Distance" here means not just geographical distance, but also the frequency of contact between two locations.

It is widely accepted that, in Silicon Valley in the U.S., networks of personal relation-

* Chung-Hua Institution for Economic Research

** Fujen University

*** National Science Council of Taiwan

**** Nagoya University

Received : 1st March 2009 Accepted : 1st June 2010

(C) 日本地域学会 (JSRSAI) 2010 
ships have contributed significantly to the dissemination of knowledge between companies and between industries, influencing the path taken by technology innovation. An industry cluster is more than just a concentration of skilled workers, suppliers and information sources; it requires linkages between various different types of organization, including universities, industrial associations, local chambers of commerce, consulting firms, public relations agencies and venture capital providers, etc., which provide technology, financing, and networking services in a way that no single enterprise could be able to match. In particular, university-based research constitutes an important source of knowledge and innovation. Jafle (1989) and Acs, Audretsch and Fledman (1992, 1994) have shown that the diffusion of knowledge created in universities stimulates innovation in the private sector.

Industry clustering can create externalities that boost the productivity of the enterprises making up the cluster. Porter (1990) points out that the intense competition between enterprises within an industry cluster enables knowledge to spread and be adopted very rapidly within the geographical region in question. Porter also notes that, during the dynamic process of industry cluster development, firms are constantly entering and leaving the cluster ; the fierce competition within the cluster forces inefficient firms to withdraw from the market. As a result, enterprises that form part of an industry cluster tend, on average, to be more competitive than other firms. Jacobs (1969) and Lucas (1988) both stress that, as a result of spatial/geographical proximity within an industry cluster, knowledge can be exchanged through various types of living activities, and that this integration of knowledge contributes to technology innovation.

Taiwan's hi-tech sector developed at a very rapid pace. This has been particularly true in the case of the electronics and IT industry, which has grown to become the single largest contributor to Taiwan's economic growth, and whose role in Taiwan's economic transformation has grown steadily more important. Taiwan's hi-tech sector has always been concentrated in Northern Taiwan. Initially, hi-tech firms were located mainly in Taipei County and Taoyuan County ; later, after the establishment of the Hsinchu Science-based Industrial Park (now the Hsinchu Science Park) in 1980, a hi-tech corridor gradually emerged that extended all the way from the Nangang Software Park in the north down to the Chunan branch of the Hsinchu Science-based Industrial Park.

A group of scholars led by Professor Hitoshi, Hirakawa of Nagoya University recently secured funding from the Japan Society for the Promotion of Science to undertake a Study of New Developments and Sustainable Symbiosis in Industry Clustering and Business Linkages in Asia, the aim of which is to compare the development of industry clusters in different parts of Asia. Implementation of that part of the study focusing on Taiwan has been undertaken on a collaborative basis by Nagoya University, the Chung-Hua Institution for Economic Research, and National Taiwan University. As part of this research project, a questionnaire survey was implemented towards the end of 2006 ; this paper seeks to analyze the results obtained in the survey. To provide further verification of the survey results, the paper begins by analyzing the emergence of the Taiwanese hi-tech sector, and especially the electronics and IT industry, focusing in particular on the semiconductor industry (where government policy support played a very important role in the industry's development). The paper then goes on to examine the formation of hi-tech industry clusters in Northern 
Taiwan, and their special characteristics. This is followed by analysis of the survey results, which targeted companies in the electronics and IT industry, with the aim of clarifying how the industry cluster effect contributed to enhanced productivity in this industry. The fourth section presents the results of statistical analysis, examining technology diffusion within the electronics and IT industry in Taiwan. The final section comprises the conclusions reached regarding the development of industry clusters in Northern Taiwan, with the aim of providing a framework for comparison with the results of similar questionnaire surveys undertaken in other parts of Asia.

\section{The Emergence of the Hi-tech Sector in Taiwan}

In the early 1980s, Taiwan was the world's leading producer of shoes, bicycles, umbrellas, electric fans, and sewing machines. By 2006, the list of products for which Taiwan was the world's leading producer nation included large-sized TFT-LCD panel, IC foundry production, IC assembly and testing, optical discs, Mask ROM, etc. The industry with the highest annual production value was the semiconductor industry, followed by the flat-panel display industry. Both of these industries belonged to the electronics and IT industry, the other sub-industries of which included electronic components manufacturing, consumer electronics, optoelectronics, instruments manufacturing, and communications hardware. The electronics and IT industry thus embraces a very wide range of products; as technology continues to develop, its scope has grown ever wider.

Taiwan's electronics and IT industry first began to take off in the 1960s. The process by which the industry evolved can be divided into three stages, in which the main focus was on assembly operations, manufacturing, and R\&D and design, respectively. By the 1970s, electronics and IT production in Taiwan had already moved beyond simple final assembly tasks towards more complex assembly processes, including the assembly of stereo systems, TV sets, video recorders, electronic calculators and various types of electrical components. In the 1980s, Taiwan's electronics and IT industry repositioned itself to focus on design and manufacturing, concentrating on technology-intensive products ; one important factor here was the decision by the Taiwanese government in the late 1970s and early 1980s to designate the electronics and IT industry as a key strategic industry, the development of which should be prioritized. 1980s saw the establishment of the Hsinchu Science-based Industrial Park, Taiwan's first hi-tech manufacturing park; the creation of this science park marked the beginning of a new era in the development of Taiwan's electronics and IT industry. The Park was soon home to a large number of new electronics and IT firms, and became synonymous with the Taiwanese hi-tech sector.

The first important date in the history of Taiwan's electronics and IT industry is 1958, when National Chiao Tung University established its Graduate Institute of Electronics. In 1964, the University set up a Semiconductor Laboratory, and in 1965 Taiwan produced its first home-grown semiconductor. Following the opening of the Kaohsiung Export Processing Zone in 1966, General Instruments began assembling transistors at its factory in the Zone, and by 1967 the company was undertaking integrated circuit assembly there. In that same year, National Chiao Tung University successfully developed Taiwan's first semiconductor wafer. 1974 saw the establishment of the Electronics Research and Service Organization (ERSO) 
within the Industrial Technology Research Institute (ITRI), which decided to introduce IC manufacturing technology from the U.S., focusing on CMOS (Complementary Metal Oxide Semiconductor) technology. In 1976, ITRI's Electronics Technology Advisory Committee decided to sign a MOS technology transfer agreement with U.S. company RCA, and sent Taiwanese personnel for training in the U.S.; the agreement guaranteed a yield rate of at least 17\%. In 1977, the personnel who had been undergoing training in the U.S. returned to Taiwan and set up a pilot IC fabrication plant at ITRI; within six months, the fab had achieved a yield rate of $70 \%$, far higher than originally anticipated. In 1978, ITRI's pilot IC fab began to accept commissions to design ICs for business enterprises; in that same year, ITRI decided to use the technology transferred from RCA to set up a new semiconductor company: United Microelectronics (UMC), which formally came into existence in 1979. Following the opening of the Hsinchu Science-based Industrial Park in 1980, UMC became the first company to set up a factory in the Park ; initially, the factory was mainly engaged in the production of ICs for use in electronic instruments, pocket calculators and TV sets.

In 1981, the same year in which IBM launched the personal computer (PC), ERSO successfully completed development of a 4-bit microcomputer IC, and began to provide IC design services to outside customers. United Microelectronics began volume production in 1982, and the company was soon experiencing rapid growth in both sales and profits. In 1983, ITRI and the National Science Council joined forces to launch the MPC project to establish IC design and CAD research capabilities within Taiwan's universities ; also in 1983, ITRI set up a VLSI (Very Large Scale Integration) experimental production facility, to stimulate the development of the Taiwanese IC design industry. In 1985, the then President of ITRI, Morris Chang, proposed that the VLSI production facility should be spun off as an independent IC foundry; this idea became a reality in 1987, with the establishment of Taiwan Semiconductor (TSMC), of which Morris Chang became Chairman. By 1988, TSMC had ramped up to volume production; the Taiwanese semiconductor industry now possessed a comprehensive vertical division of labor, covering every stage from IC design, through IC foundry production to IC assembly and testing, laying the foundations for the ongoing development of Taiwan's electronics and IC industry.

The chief characteristics of Taiwan's electronics and IT industry thus include the vertical integration model referred to above. In the semiconductor industry, each segment of the value chain-IC design, IC foundry production, assembly and testing - has large numbers of competing firms. This is a completely different model from that of the integrated device manufacturer (IDM) that undertakes every stage in the IC production process inhouse. The vertical distribution of labor that characterizes Taiwan's semiconductor industry has unquestionably helped to raise the overall level of technology in the industry, while also ensuring efficient utilization of production capacity and shortening time-to-market. Another important feature of the industry is its profit-sharing system. The employees of semiconductor firms often have the opportunity to subscribe to shares in their company at the shares' face value when the firm a cash capital increment (and the amount of tax that the employees have to pay on this is very low). This system helps semiconductor firms to attract and keep talented people, and also gives employees an incentive to do their utmost for the company. While this system has its drawbacks-including the risk of stock price 
manipulation and an unfair distribution of the tax burden - it has definitely helped the Taiwanese electronics and IT sector to achieve faster growth than most other industries.

\section{Industry Cluster Formation in Northern Taiwan}

Taiwan's first hi-tech industry cluster developed around the Hsinchu Science-based Industrial Park (now the Hsinchu Science Park), which was founded in 1980. Over the years, the Taiwanese government has invested a total of NT $\$ 59.6$ billion in developing and improving the Park's infrastructure (both "hardware" and "software"). There are currently more than 400 companies located in the Park, with a combined total of over 120,000 employees; in 2007, the firms located in the Park posted combined annual sales revenue of NT\$1.15 trillion (Table 1). The success of the Hsinchu Science-based Industrial Park is closely related to the first-rate infrastructure that the government has provided for it. Government agencies provided more than just the basic Park facilities; they have also assisted with the provision of technology, offering impressive support for both new business start-up and market formation. The comparison of the development of Taiwan's PC industry and its semiconductor industry presented in Tain-Jy Chen (2008) shows that the government played a very important role in industry cluster formation in the semiconductor industry.

The Hsinchu Science-based Industrial Park was established in accordance with the government's goal of re-orienting Taiwan's industrial structure away from labor-intensive industries towards technology-intensive industries. The reason for choosing Hsinchu as the location for Taiwan's first science park was the presence nearby of two leading universities - National Chiao Tung University and National Tsinghua University - and of the Industrial Technology Research Institute (ITRI). The Hsinchu Science-based Industrial Park was modeled on Silicon Valley in the U.S., and was carefully planned, even to the extent of specifying the ratio of green space to buildings. The Park's links to Silicon Valley were always very important, and this was particularly true with respect to the semiconductor industry. The large number of ethnic Chinese engineers moving back and forth between jobs in Silicon Valley and jobs in the Hsinchu Science-based Industrial Park constituted the

Table 1. The Growth of the Hsinchu Science-based Industrial Park (1981-2007)

\begin{tabular}{|c|c|c|c|c|c|c|c|c|c|c|c|c|c|c|}
\hline Year & 1981 & 1982 & 1983 & 1984 & 1985 & 1986 & 1987 & 1988 & 1989 & 1990 & 1991 & 1992 & 1993 & 1994 \\
\hline firms & 17 & 26 & 37 & 44 & 50 & 59 & 77 & 94 & 105 & 121 & 137 & 140 & 150 & 165 \\
\hline employees & - & - & 3,583 & 6,490 & 6,670 & 8,275 & 12,201 & 16,445 & 19,071 & 22,356 & 23,297 & 25,148 & 28,416 & 33,538 \\
\hline $\begin{array}{l}\text { capitalization } \\
\text { (billion NTD) }\end{array}$ & 0.72 & 1.16 & 1.96 & 3.23 & 4.06 & 5.71 & 10.56 & 15.83 & 28.22 & 42.69 & 55.11 & 62.83 & 66.89 & 93.50 \\
\hline $\begin{array}{c}\text { annual sales } \\
\text { revenue } \\
\text { (billion NTD) }\end{array}$ & - & - & 3.0 & 9.5 & 10.5 & 17.0 & 27.5 & 49.0 & 55.9 & 65.6 & 77.7 & 87.0 & 129.0 & 177.8 \\
\hline Year & 1995 & 1996 & 1997 & 1998 & 1999 & 2000 & 2001 & 2002 & 2003 & 2004 & 2005 & 2006 & \multicolumn{2}{|c|}{2007} \\
\hline firms & 180 & 203 & 245 & 272 & 292 & 289 & 312 & 334 & 369 & 384 & 382 & 392 & \multicolumn{2}{|c|}{413} \\
\hline employees & 42,257 & 54,806 & 68,410 & 72,623 & 82,822 & 96,642 & 96,293 & 98,616 & 101,763 & 113,011 & 114,963 & 121,762 & \multicolumn{2}{|c|}{129,512} \\
\hline $\begin{array}{l}\text { capitalization } \\
\text { (billion NTD) }\end{array}$ & 147.7 & 258.5 & 375.65 & 510.63 & 566.02 & 694.48 & 858.82 & 909.99 & 992.45 & $1,050.1$ & $1,040.2$ & $1,163.9$ & \multicolumn{2}{|c|}{$1,151.4$} \\
\hline $\begin{array}{l}\text { annual sales } \\
\text { revenue } \\
\text { (billion NTD) }\end{array}$ & 299.2 & 318.1 & 399.7 & 455.0 & 650.9 & 929.3 & 662.5 & 705.4 & 857.8 & $1,085.9$ & 987.9 & $1,120.9$ & \multicolumn{2}{|c|}{$1,146.2$} \\
\hline
\end{tabular}

Source: The Hsinchu Science Park Administration website. 
foundations on which the Park's success was based (Tain-Jy Chen, 2008). The nearby universities and research institutes provided the Hsinchu Science-based Industrial Park with a steady supply of high-caliber manpower, while the government provided support in terms of tax breaks for the importation of production machinery and materials, subsidized rental of sites for factory construction, and a five-year exemption from business income tax for new businesses. The government also supported the development of incubator centers, which helped to stimulate entrepreneurial activity. These factors correspond exactly with the three key requirements for successful hi-tech industry cluster development identified by Bresnathan, Gambardella and Saxenian (2001).

In reality, the Hsinchu Science-based Industrial Park was not an overnight success.

Table 2. The Relative Importance of Individual Industries Within the Hsinchu Science-based Industrial Park

Unit : 100 milion NTO

\begin{tabular}{|c|c|c|c|c|c|c|c|}
\hline Industry & IC & $\begin{array}{l}\text { PC peripherals } \\
\text { manufacturers }\end{array}$ & $\begin{array}{l}\text { Communications } \\
\text { Industries }\end{array}$ & $\begin{array}{l}\text { optoelectronics } \\
\text { industries }\end{array}$ & $\begin{array}{l}\text { Measuring } \\
\text { Instruments }\end{array}$ & $\begin{array}{l}\text { biotech } \\
\text { Industries }\end{array}$ & Total \\
\hline 1984 & 16.00 & 72.00 & 5.00 & 0.70 & 1.30 & 0.00 & 95.00 \\
\hline 1985 & 17.00 & 79.00 & 6.00 & 1.50 & 1.80 & 0.03 & 105.33 \\
\hline 1986 & 32.91 & 118.66 & 9.65 & 6.05 & 2.72 & 0.44 & 170.43 \\
\hline 1987 & 38.09 & 199.06 & 23.48 & 12.18 & 2.69 & 1.85 & 277.35 \\
\hline 1988 & 68.08 & 353.26 & 45.00 & 15.99 & 3.00 & 4.53 & 489.86 \\
\hline 1989 & 116.57 & 345.92 & 69.85 & 13.90 & 5.81 & 7.13 & 559.18 \\
\hline 1990 & 146.49 & 370.34 & 113.60 & 11.43 & 8.18 & 5.58 & 655.65 \\
\hline 1991 & 233.17 & 373.44 & 135.65 & 18.21 & 10.46 & 5.78 & 776.71 \\
\hline 1992 & 322.14 & 385.71 & 124.48 & 20.18 & 13.28 & 4.59 & 870.38 \\
\hline 1993 & 558.39 & 541.77 & 134.70 & 35.64 & 16.22 & 2.87 & $1,289.59$ \\
\hline 1994 & 840.85 & 719.08 & 147.29 & 47.24 & 19.46 & 3.72 & $1,777.64$ \\
\hline 1995 & $1,479.50$ & $1,215.44$ & 170.02 & 100.29 & 24.92 & 2.01 & $2,992.18$ \\
\hline 1996 & $1,570.53$ & $1,212.37$ & 192.63 & 175.34 & 27.68 & 2.47 & $3,181.47$ \\
\hline 1997 & $1,998.84$ & $1,409.62$ & 271.32 & 278.49 & 34.14 & 4.04 & $3,996.46$ \\
\hline 1998 & $2,308.29$ & $1,598.94$ & 264.48 & 297.60 & 75.02 & 5.69 & $4,550.02$ \\
\hline 1999 & $3,608.01$ & $2,008.96$ & 323.99 & 513.88 & 47.95 & 6.65 & $6,509.44$ \\
\hline 2000 & $5,757.11$ & $2,124.89$ & 507.70 & 809.22 & 72.58 & 11.34 & $9,292.65$ \\
\hline 2001 & $3,757.19$ & $1,610.71$ & 561.23 & 623.55 & 47.97 & 13.35 & $6,613.99$ \\
\hline 2002 & $4,562.59$ & $1,245.28$ & 565.58 & 600.35 & 53.89 & 14.16 & $7,041.88$ \\
\hline 2003 & $5,632.75$ & $1,347.71$ & 564.59 & 943.35 & 57.89 & 18.41 & $8,564.71$ \\
\hline 2004 & 7,427.38 & $1,382.45$ & 605.30 & $1,312.63$ & 92.47 & 25.39 & $10,859.22$ \\
\hline 2005 & $6,851.10$ & $1,018.80$ & 485.27 & $1,372.64$ & 98.18 & 29.97 & $9,879.34$ \\
\hline 2006 & $7,947.94$ & $1,014.96$ & 452.65 & $1,605.98$ & 132.84 & 30.63 & $11,208.54$ \\
\hline 2007 & $8,192.14$ & 949.46 & 372.63 & $1,779.55$ & 112.88 & 31.49 & $11,462.02$ \\
\hline
\end{tabular}

Source: Same as Table 1. 
The companies that moved into the Park when it was first established in 1980 were mostly PC and PC peripherals manufacturers. By and large, these were well-established firms (such as Acer and Mitac), not start-ups, and had moved to the Park in order to benefit from the tax breaks that it offered. Most of them were engaged in contract manufacturing for foreign companies ; their export-oriented manufacturing involved relatively little R\&D. In its early days, therefore, the Hsinchu Science-based Industrial Park did not really possess the characteristics that one usually associates with a hi-tech industry cluster ; there was little in the way of knowledge diffusion.

Both government-established development funds and venture capital firms offered financing support to stimulate R\&D activity. Initially, however, this venture capital funding was taken up only by a handful of engineer-entrepreneurs who had returned to Taiwan after working in the U.S. Owing to the relatively low technology levels of most of the companies that established themselves in the Hsinchu Science-based Industrial Park in the early years, and the low value-added of their products, there was no real industry cluster formation as such. The characteristics normally associated with an industry cluster include knowledge diffusion, the possession of world-class technology, branded manufacturing and the transmission of technology through the movement of individual personnel between companies. Up until 1990, however, nearly half (47.7\%) of the companies located in the Hsinchu Sciencebased Industrial Park were mature firms, 29.4\% were in the growth stage, and only $21.8 \%$ were start-ups (CIER, 1990).

It was not until the semiconductor industry became a major feature of the Hsinchu Science-based Industrial Park that the industry cluster effect started to develop. By 1993, the annual production value of the semiconductor firms located in the Park had surpassed that of the PC and PC peripherals manufacturers, and by 2007 the semiconductor industry contributed over $70 \%$ of the Park's total annual production value (Table 2).

Just how important the Hsinchu Science-based Industrial Park has become to the global hi-tech sector did not become obvious until September 1999, when an earthquake measuring 7.3 on the Richter scale hit Taiwan, causing extensive damage, and sending spot prices in the global semiconductor market through the roof. The whole world was now aware of the importance of the Park to the global semiconductor industry as a whole. Both UMC and TSMC had benefited significantly from government support, participating alongside privatesector companies in major government projects, and also benefitting from their involvement in the 5-year plan to develop VLSI technology. When the government decided to close down ITRI's VLSI pilot plant, some of the personnel who had been working there decided to set up their own private-sector IC foundry, which became Winbond Electronics. Subsequently, when Macronix was established, it too benefited from government venture capital funding. The emergence of these new IC foundries led to a mushrooming of IC design houses, such as Realtek, Sunplus, and SIS.

IC design houses require relatively little capital to set up; at the same time, the proximity of IC foundries helps to make their products more competitive. The growth of the IC design sector in Taiwan can thus be seen as deriving from the agglomeration of positive externalities caused by the establishment of the IC foundries. Eventually, UMC spun off its IC design unit and repositioned itself as a specialist IC foundry. The fierce 
competition between UMC and TSMC contributed to the growth of specialist mask, testing and assembly firms, giving the Taiwanese semiconductor industry a comprehensive vertical division of labor. By the time that a fully-fledged semiconductor industry cluster emerged in the Hsinchu Science-based Industrial Park in 1994-1995, 13 years had elapsed since UMC began volume production back in 1982 .

The success of the Hsinchu Science-based Industrial Park provided a major stimulus for industry cluster development in Taiwan, turning Taiwan into a veritable "Technology Island." In Northern Taiwan, by 1999 planning was underway for the creation of the Chunan branch of the Hsinchu Science-based Industrial Park, which would focus on the biotech, communications and optoelectronics industries; by March 2008, 31 companies had already established themselves in the Chunan site. The Hwa Ya Technology Park, near Linkou, was established by the Formosa Plastics Group in 1994. Several leading companies-including Nanya Technology Corporation, Quanta, and CMC - located themselves in this park, which developed into the closest semiconductor industry cluster to Taipei City.

Work on the construction of the Neihu Technology Park in Taipei began in 1987. By 1995, several major electronics manufacturers had located their operational and R\&D headquarters in the Park ; by 2007, the Park was home to 3,042 firms, with a combined total of 120,064 employees, and combined annual sales of NT $\$ 2.2$ trillion. Construction of the Nangang Business Park began in 1992, with the first part of the facility opening in August 1999. A large number of computer, electronics, IT and telecommunications manufacturers have located their R\&D divisions in the Nangang Business Park, which is also home to many automation design firms and IC design houses. The Nangang Software Park, which forms part of the Nangang Business Park, is currently home to 275 individual enterprises, with a total of over 13,000 employees, and combined annual sales revenue in excess of NT $\$ 200$ billion. A Nangang branch of the Taipei World Trade Center is also being established near the Nangang Business Park, and the Park benefits from the presence nearby of research institutions such as the Academia Sinica. With abundant land available for office and factory building construction, and with special semiconductor and digital content academies having been established in the area, the Nangang Business Park has developed into the main center for the software industry in Northern Taiwan, with almost unlimited potential for future growth.

In 2006, the Honhai Group, which has attracted a great deal of attention over the past few years, established a new science park in the Dingpu district of Tucheng City in Taipei County. Most of the companies located in the park are small and medium-sized component manufacturers that supply Honhai, but the park is gradually being transformed to serve as the center for Honhai's R\&D operations, and the home of electronics, chemicals and metallurgy industry clusters.

An innovation and high technology $\mathrm{R} \& \mathrm{D}$ corridor is gradually taking shape that runs right down the west coast of Taiwan. It extends south from the existing hi-tech corridor between Hsinchu and Taipei to take in the Central Science-based Industrial Park, the Tainan Science-based Industrial Park and the Tainan Technology Industrial Park, as well as the six new specialist production and R\&D zones that have been planned along the route taken by Taiwan's High Speed Rail line; these include the Nangang Biotech Park, the Hsinchu 
Biomedical Park, the Taichung Precision Machinery Park, the Dapumei Precision Machinery Park in Chiayi County, the Tainan High Speed Rail Research Community, and the Kaohsiung Software Park. Taiwan has been moving away from the resource-driven economic development model of the past towards an investment-driven, and now an innovation-driven, development model. According to the World Economic Forum's Global Competitiveness Report 2007-2008, Taiwan ranked number one in the world in terms of the "State of Cluster Development" in 2006 and again in 2007 ; Taiwan has thus won international recognition as a model of successful industry cluster development.

\section{The Results Obtained in the Questionnaire Survey of the Taiwanese Electronics and IT Industry}

As part of the project to undertake international comparison of industry cluster development in Japan, Taiwan and South Korea, a survey of industry clusters in Taiwan was undertaken jointly by Nagoya University, the Chung-Hua Institution for Economic Research, and the Taiwan Electrical and Electronic Manufacturers' Association (TEEMA). A questionnaire survey regarding industry clustering, business collaboration and technology innovation was administered to 3,608 TEEMA member companies, 1,279 Taiwan Association of Machinery Industry (TAMI) member companies and 425 companies located in the Hsinchu Science Park over the period from December 2006 to February 2007, to study the characteristics of industry clusters in Taiwan, and particularly electronics and IT industry clusters in Northern Taiwan. 205 completed questionnaires were returned (representing a return rate of $3.9 \%$ ), of which 200 were valid. The questionnaire was divided into three parts (Company Overview, Operational Performance and Innovation Activity, and Network Establishment), with a total of 21 items. The results obtained for these 21 items are analyzed below.

\subsection{Company Overview}

Q1 : Regarding company location, of the 200 valid returned questionnaires, 130 respondents (65.0\% of the total) were located in the Taipei metropolitan area, 28 (14.0\%) were located in the Hsinchu Science Park or the surrounding area, and 42 (21.0\%) were located in Central or Southern Taiwan. $80 \%$ of the respondents were located in or north of the Hsinchu area, which is consistent with the geographical concentration of the Taiwanese electronics and IT industry as described above.

Q2 : As regards the company's date of establishment, 49 respondents (24.5\% of the total) had been in existence since 1979 or earlier, 59 (29.5\%) were established during the period 1980-1989, and 92 (46.0\%) had been established since 1990. Of the 130 respondents located in the Taipei metropolitan area, 60 (46.2\%) had come into existence since 1990 ; of the 28 respondents located in the Hsinchu area, 20 (71.4\%) had been established since 1990. This distribution reflects the fact that Taiwan's IT sector has developed largely in Northern Taiwan, and mainly after the establishment of the Hsinchu Science-based Industrial Park in 1980.

Q3: With regard to the highest educational qualification held by the company's CEO, the largest share (127, or $63.5 \%$ of the total) held a bachelor's degree or higher from a Taiwanese university. $43(21.5 \%)$ held a bachelor's degree or higher from a foreign 
university; 24 (12.0\%) had been educated to below university level, and 6 (3\%) refused to answer. Of the 127 company CEOs who held a bachelor's degree or higher from a Taiwanese university, 24 (18.9\%) held a master's degree or Ph.D. Of the 43 who held a bachelor's degree or higher from a foreign university, 29 (67.4\%) held a master's degree or Ph.D. ; of these 29, 25 had studied in the U.S. and 2 had studied in Japan. These data reflect the fact that the U.S. has traditionally been the preferred destination for Taiwanese students wishing to study overseas, with the U.S. also offering the best opportunities to acquire meaningful work experience before returning to Taiwan to work or start a business.

Q4 : 59 of the 200 enterprises (29.5\%) were IT-related assembly firms or system manufacturers. $69(34.5 \%)$ were IT-related materials, equipment or component suppliers, and $64(32.0 \%)$ were software firms or providers of financial, accounting, consulting, legal or manpower services. 8 firms refused to answer.

Q5 : 26 enterprises (13.0\% of the total) reported that they were mainly engaged in $R \& D$, $29(14.5 \%)$ were engaged in distribution or sales, and $143(71.5 \%)$ were engaged in manufacturing. Manufacturing was thus by far the largest segment. Of the 26 enterprises that gave $R \& D$ as their main business activity, 17 were located in the Taipei metropolitan area, 8 were located in the Hsinchu area, and only 1 was located in Central/Southern Taiwan. There is thus a pronounced concentration of R\&D activity in Northern Taiwan. Another point worth noting is that, whereas only $13.2 \%$ of the respondents located in the Taipei metropolitan area were mainly engaged in R\& $\mathrm{D}$, the figure was $28.6 \%$ for firms located in the Hsinchu area, reflecting Hsinchu's prominence as the center of a hi-tech industry cluster.

Q6: As regards the location of the enterprise's main manufacturing facility, of the 180 enterprises that answered this question, 100 (55.3\%) reported that their main manufacturing facility was in "Taiwan-Other", 30 (16.6\%) reported their main manufacturing facility was in the Hsinchu area, and 51 (28.3\%) reported that their main manufacturing facility was overseas. Of the 51 firms whose main manufacturing facility was located overseas, $45(88.2 \%)$ had their main manufacturing facility in China, 3 had it in the U.S., 2 had it in Japan, and 1 had it in Germany. Given that personnel costs tend to account for only a relatively low share of the total production costs of hi-tech enterprises, it is not surprising that some firms should have chosen to locate their manufacturing bases in the advanced nations, where they would have ready access to new technology. As regards the location of secondary manufacturing facilities, 49 enterprises $(27.1 \%$ ) reported that their secondary manufacturing facilities were located overseas, mainly in China (particularly Shenzhen, Suzhou, and Dongguan) ; other overseas locations for secondary manufacturing facilities included Malaysia, Thailand, the Philippines, and South Korea.

Among IT-related assembly firms and system manufacturers, 19 (33.4\%) had their main manufacturing facility overseas (mainly in China) ; the figure for raw material and component manufacturers was $21(32.8 \%)$. The corresponding figures for secondary manufacturing facilities were $18(47.3 \%)$ and $10(38.1 \%)$, respectively. It can thus be seen that there is a very pronounced tendency for Taiwanese companies in the 
hi-tech sector to locate their manufacturing facilities in China.

With regard to the relationship between the location of the company's headquarters and the location of its main manufacturing facility, of the 120 firms based in the Taipei metropolitan area, 56.7\% had their main manufacturing facility in Taiwan. Adding in another $10 \%$ for those firms headquartered in Hsinchu who had their main manufacturing facility in Taiwan, it can be seen that around two-thirds of the respondent companies had their main manufacturing facility in Taiwan, with another one-third having it overseas. Of the 28 companies whose headquarters were in the Hsinchu area, 22 (81.8\%) also had their main manufacturing facility in the Hsinchu area; only $18.2 \%$ had it located overseas. However, if one considers secondary manufacturing facilities, then the situation is rather different; $31.4 \%$ of the enterprises whose headquarters were in Hsinchu had a secondary manufacturing facility located overseas (the corresponding figure for companies headquartered in Taipei was $47.3 \%$ ). Overall, Taiwan's electronics and IT industry displays a high degree of internationalization with respect to its manufacturing operations.

Q7: Of the 200 companies that submitted valid responses, 88 (44.0\%) had less 50 employees, 65 (32.5\%) had between 50 and 300 employees, and 46 (23.0\%) had over 300 employees (Table 3 ).

If enterprise size is compared with enterprise location, age, and the educational attainment of the chairman/president, then the following results are obtained: Of the companies located in the Hsinchu area, $20.8 \%$ had over 300 employees, and $17.9 \%$ had less than 30 employees; for companies located in the Taipei metropolitan area, the corresponding percentages were $20.8 \%$ and $30.0 \%$, and for companies located in Central or Southern Taiwan, they were $21.4 \%$ and $33.3 \%$, respectively. Clearly, the Hsinchu area has a larger share of large companies, while in both the Taipei metropolitan area and Central/Southern Taiwan smaller firms with fewer than 30 employees account for over $30 \%$ of all enterprises in the region. Longer-established companies tend to be larger, while younger companies tend to be small; of those enterprises established in 1979 or earlier, 30.6\% had over 300 employees, whereas among those established since 1990, 30.04\% had less than 30 employees. As regards the relationship between enterprise size and the educational attainment of the president or chairman, the survey data indicate that only $18.6 \%$ of firms with fewer than 30 employees had president/chairman with a bachelor's degree or higher from a foreign university ; for enterprises with more than 300 employees, the percentage was $39.53 \%$. These data suggest that having been educated at an overseas university is associated with having larger enterprise size.

Q8: With regard to capitalization, 92 of the enterprises in the survey (46.0\% of the total) had between NT $\$ 10$ million and NT $\$ 100$ million in capital, $45(22.5 \%)$ had between NT $\$ 100$ million and NT\$1 billion, and 35 (17.5\%) had less than NT\$10 million. Of the 28 enterprises located in the Hsinchu area, 11 (39.3\%) had between NT $\$ 100$ million and NT $\$ 1$ billion in capital, and 6 (21.4\%) had capitalization of over NT $\$ 1$ billion. Out of 130 enterprises located in the Taipei metropolitan area, 65 (50\%) had capitalization of between NT $\$ 10$ million and NT $\$ 100$ million, and 29 (22.3\%) had 
between $\mathrm{NT} \$ 100$ million and $\mathrm{NT} \$ 1$ billion in capital. Of the 42 enterprises in Central/Southern Taiwan, 22 (52.4\%) had between $\mathrm{NT} \$ 10$ million and NT $\$ 100$ million in capital, and $9(21.4 \%)$ had less than NT $\$ 10$ million in capital. It can thus be seen that enterprises located in the Hsinchu area tend to be larger.

$75.5 \%$ of the 200 respondents reported that they were $100 \%$ Taiwanese-owned; 22 firms $(11.0 \%$ of the total) were less than $60 \%$ Taiwanese-owned. Of the 28 enterprises located in the Hsinchu area, 19 firms (67.9\% of the total) were $100 \% \mathrm{Ta}$ iwanese-owned, compared to 95 out of 130 firms in the Taipei metropolitan area (73.1\%), and 37 out of 42 firms in Central/Southern Taiwan (88.1\%). The Hsinchu area thus has the largest share of foreign-invested firms.

Q9: Of the 200 respondents, 150 firms (75\% of the total) had made a profit in both of the previous two years (2004 and 2005) ; 49 firms (24.5\%) had made a loss in one of the previous two years. The Taipei metropolitan area had the highest percentage of firms that had made a profit in both 2004 and 2005, at $82.3 \%$, followed by Central/ Southern Taiwan with $66.7 \%$; the Hsinchu region had the lowest share, at $53.6 \%$. $87.8 \%$ of enterprises that had been established in 1979 or earlier had made a profit in both 2004 and 2005, compared to $76.3 \%$ of those established between 1980 and 1989, and 67.4\% of those established since 1990. Enterprises whose CEO held a bachelor's degree or higher from a foreign university were less likely to have made a profit in both 2004 and 2005 than those whose CEO held a bachelor's degree or higher from a Taiwanese university. There did not appear to be any significant correlation between the sub-industry to which an enterprise belonged and whether it had made a profit in both 2004 and 2005 .

\subsection{Operational Performance and Innovation Activity}

Q10 : $57.5 \%$ of respondents reported engaging in product innovation within the past three years ; only $3.5 \%$ had not done so. $43.0 \%$ of enterprises had undertaken manufacturing process innovation within the past three years, compared to just $6.0 \%$ who had not ; $37.0 \%$ of enterprises had undertaken management innovation, whereas $10.0 \%$ had not. $17.5 \%$ of enterprises had been actively engaged in the purchase of intellectual property, while $38.5 \%$ had not. The relative lack of interest in acquiring intellectual property from external sources suggests that most of the enterprises included in the survey were not dependent on cutting-edge technology.

$62.7 \%$ of IT-related assembly firms and system manufacturers had engaged in technology innovation within the past three years, while $52.2 \%$ of materials and component suppliers had undertaken process innovation. This supports the view that Taiwanese enterprises' innovation activity is mainly oriented towards product and process innovation.

Of the companies located in the Hsinchu area, 75.0\% had engaged in production innovation within the past three years, $46.4 \%$ had undertaken process innovation, and $50.0 \%$ had undertaken management innovation; $25.0 \%$ had been actively involved in the purchase of intellectual property. Overall, firms located in the Hsinchu area appeared to have a more proactive attitude towards innovation than 
Table 3. Cross-tabulation of the No. of Employees, Enterprise Location, Enterprise Age, etc.

(Unit: No of industry; \%)

\begin{tabular}{|c|c|c|c|c|c|c|c|c|c|c|c|c|c|c|c|}
\hline & $\begin{array}{l}\text { employees } \\
(2006 \text { 年) }\end{array}$ & count & \begin{tabular}{|c|} 
1) \\
fewer \\
than 30
\end{tabular} & $\begin{array}{c}\text { 2) } \\
30-49\end{array}$ & $\begin{array}{c}3) \\
50-99\end{array}$ & $\begin{array}{c}\text { 4) } \\
100-299\end{array}$ & $\begin{array}{l}\text { 5) } \text { over } \\
300\end{array}$ & $\begin{array}{c}\text { Refused } \\
\text { to } \\
\text { answer }\end{array}$ & $\begin{array}{l}\text { 1) } \\
\text { fewer } \\
\text { than } 30\end{array}$ & $\begin{array}{l}\text { 2) } \\
30-49\end{array}$ & $\begin{array}{c}3) \\
50-99\end{array}$ & \begin{tabular}{|c|} 
4) \\
$100-299$
\end{tabular} & $\begin{array}{c}5) \\
\text { over } 300\end{array}$ & $\begin{array}{l}\text { Refused } \\
\text { to } \\
\text { answer }\end{array}$ & Total \\
\hline \multicolumn{16}{|c|}{ 1. Enterprise Location (Q1) } \\
\hline 1 & $\begin{array}{l}\text { Taipei } \\
\text { metropolitan area }\end{array}$ & 130 & 39 & 20 & 26 & 17 & 27 & 1 & 30.00 & 15.38 & 20.00 & 13.08 & 20.77 & 0.77 & 100.0 \\
\hline 2 & Hsinchu area & 28 & 5 & 5 & 2 & 6 & 10 & 0 & 17.86 & 17.86 & 7.14 & 21.43 & 35.71 & 0.00 & 100.0 \\
\hline \multirow[t]{2}{*}{3} & Central/Southern & 42 & 14 & 5 & 8 & 6 & 9 & 0 & 33.33 & 11.90 & 19.05 & 14.29 & 21.43 & 0.00 & 100.0 \\
\hline & Total & 200 & 58 & 30 & 36 & 29 & 46 & 1 & 29.00 & 15.00 & 18.00 & 14.50 & 23.00 & 0.50 & 100.0 \\
\hline \multicolumn{16}{|c|}{ 2. enterprise size $(\mathrm{Q} 7)$} \\
\hline 1 & fewer than 30 & 58 & 58 & 0 & 0 & 0 & 0 & 0 & 100.00 & 0.00 & 0.00 & 0.00 & 0.00 & 0.00 & 100.0 \\
\hline 2 & $30-49$ & 30 & 0 & 30 & 0 & 0 & 0 & 0 & 0.00 & 100.00 & 0.00 & 0.00 & 0.00 & 0.00 & 100.0 \\
\hline 3 & $50-99$ & 36 & 0 & 0 & 36 & 0 & 0 & 0 & 0.00 & 0.00 & 100.00 & 0.00 & 0.00 & 0.00 & 100.0 \\
\hline 4 & $100-299$ & 29 & 0 & 0 & 0 & 29 & 0 & 0 & 0.00 & 0.00 & 0.00 & 100.00 & 0.00 & 0.00 & 100.0 \\
\hline \multirow[t]{3}{*}{5} & Over 300 & 46 & 0 & 0 & 0 & 0 & 46 & 0 & 0.00 & 0.00 & 0.00 & 0.00 & 100.00 & 0.00 & 100.0 \\
\hline & Refused to answer & 1 & 0 & 0 & 0 & 0 & 0 & 1 & 0.00 & 0.00 & 0.00 & 0.00 & 0.00 & 100.00 & 100.0 \\
\hline & Total & 200 & 58 & 30 & 36 & 29 & 46 & 1 & 29.00 & 15.00 & 18.00 & 14.50 & 23.00 & 0.50 & 100.0 \\
\hline \multicolumn{16}{|c|}{ 3. Industry (Q9) } \\
\hline 1 & profit in both years & 150 & 43 & 26 & 27 & 19 & 34 & 1 & 28.67 & 17.33 & 18.00 & 12.67 & 22.67 & 0.67 & 100.0 \\
\hline \multirow[t]{3}{*}{2} & $\begin{array}{l}\text { a loss in one of the } \\
\text { previous two years }\end{array}$ & 49 & 14 & 4 & 9 & 10 & 12 & 0 & 28.57 & 8.16 & 18.37 & 20.41 & 24.49 & 0.00 & 100.0 \\
\hline & Refused to answer & 1 & 1 & 0 & 0 & 0 & 0 & 0 & 100.00 & 0.00 & 0.00 & 0.00 & 0.00 & 0.00 & 100.0 \\
\hline & Total & 200 & 58 & 30 & 36 & 29 & 46 & 1 & 29.00 & 15.00 & 18.00 & 14.50 & 23.00 & 0.50 & 100.0 \\
\hline \multicolumn{16}{|c|}{ 4. Year of Establishment (Q2) } \\
\hline 1 & $\sim 1979$ & 49 & 6 & 7 & 14 & 7 & 15 & 0 & 12.24 & 14.29 & 28.57 & 14.29 & 30.61 & 0.00 & 100.0 \\
\hline 2 & 1980-1989 & 59 & 17 & 8 & 10 & 10 & 13 & 1 & 28.81 & 13.56 & 16.95 & 16.95 & 22.03 & 1.69 & 100.0 \\
\hline \multirow[t]{2}{*}{3} & $1990 \sim$ & 92 & 35 & 15 & 12 & 12 & 18 & 0 & 38.04 & 16.30 & 13.04 & 13.04 & 19.57 & 0.00 & 100.0 \\
\hline & Total & 200 & 58 & 30 & 36 & 29 & 46 & 1 & 29.00 & 15.00 & 18.00 & 14.50 & 23.00 & 0.50 & 100.0 \\
\hline \multicolumn{16}{|c|}{ 5. CEO Highest Educational Degree (Q3) } \\
\hline 1 & $\begin{array}{l}\text { A bachelor's } \\
\text { degree or higher } \\
\text { from a Taiwanese } \\
\text { university }\end{array}$ & 127 & 40 & 23 & 23 & 16 & 25 & 0 & 31.50 & 18.11 & 18.11 & 12.60 & 19.69 & 0.00 & 100.0 \\
\hline 2 & $\begin{array}{l}\text { a bachelor's degree } \\
\text { or higher from a } \\
\text { foreign university }\end{array}$ & 43 & 8 & 2 & 7 & 9 & 17 & 0 & 18.60 & 4.65 & 16.28 & 20.93 & 39.53 & 0.00 & 100.0 \\
\hline \multirow[t]{3}{*}{3} & $\begin{array}{l}\text { had been educated } \\
\text { to below university } \\
\text { level }\end{array}$ & 24 & 8 & 3 & 5 & 4 & 4 & 0 & 33.33 & 12.50 & 20.83 & 16.67 & 16.67 & 0.00 & 100.0 \\
\hline & Refused to answer & 6 & 2 & 2 & 1 & 0 & 0 & 1 & 33.33 & 33.33 & 16.67 & 0.00 & 0.00 & 16.67 & 100.0 \\
\hline & Total & 200 & 58 & 30 & 36 & 29 & 46 & 1 & 29.00 & 15.00 & 18.00 & 14.50 & 23.00 & 0.50 & 100.0 \\
\hline \multicolumn{16}{|c|}{ 6. main manufacturing facility (Q6A) } \\
\hline 1 & Hsinchu area & 30 & 9 & 3 & 3 & 6 & 9 & 0 & 30.00 & 10.00 & 10.00 & 20.00 & 30.00 & 0.00 & 100.0 \\
\hline 2 & Taiwan-Other & 100 & 26 & 16 & 28 & 11 & 18 & 1 & 26.00 & 16.00 & 28.00 & 11.00 & 18.00 & 1.00 & 100.0 \\
\hline \multirow[t]{3}{*}{3} & overseas & 51 & 15 & 5 & 3 & 12 & 16 & 0 & 29.41 & 9.80 & 5.88 & 23.53 & 31.37 & 0.00 & 100.0 \\
\hline & Refused to answer & 19 & 8 & 6 & 2 & 0 & 3 & 0 & 42.11 & 31.58 & 10.53 & 0.00 & 15.79 & 0.00 & 100.0 \\
\hline & Total & 200 & 58 & 30 & 36 & 29 & 46 & 1 & 29.00 & 15.00 & 18.00 & 14.50 & 23.00 & 0.50 & 100.0 \\
\hline
\end{tabular}

Source: Joint Questionnairc survey undertaken by Nagoya University and the Chung-Hua Institution for Economic Research.

those in other regions. It was noticeable that enterprises established since 1990 displayed more enthusiasm for all types of innovation than those established prior to that date. Larger enterprises also tended to have a more proactive attitude towards innovation. The overall level of innovation activity can thus be seen to be closely linked to whether a firm is located in the Hsinchu area, how long it has been in existence, and how large it is (Figure 1). 


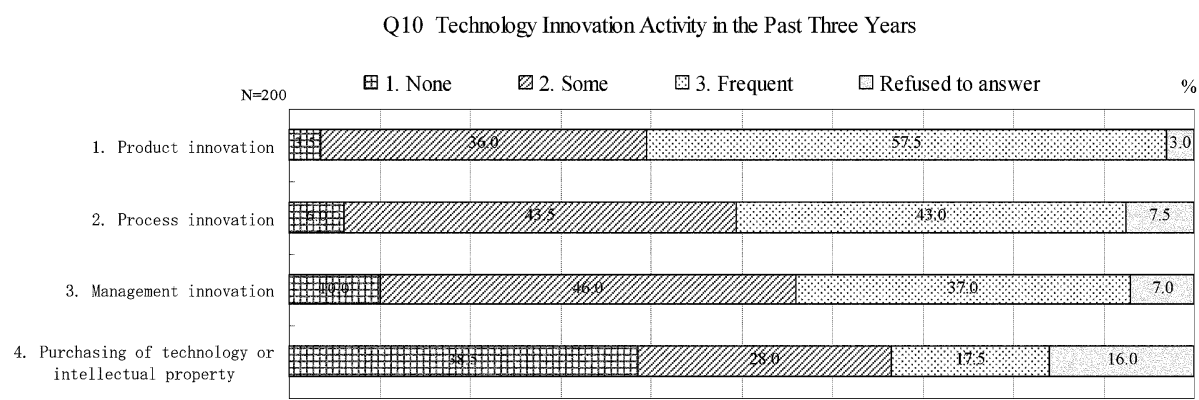

Figure 1. Enterprises' Technology Innovation Activity in the Past Three Years Source: Same as Table 3.

Q11: As regards the channel through which enterprises obtained technology, for $72.0 \%$ of enterprises the main method for acquiring technology was in-house R\&D; the next most common method was collaborative technology development with partner companies $(14.0 \%)$, followed by cross-industry collaboration $(5.0 \%)$. With regard to secondary avenues for acquiring technology, here the most common method was collaborative development with partner companies (28.5\%) ; as for the third most important avenue for acquiring technology, for $24.5 \%$ of firms this was the retention of valuable human resources. The calculations for this question were implemented by allocating 5 points for the most important method of technology acquisition, 3 points for the second most important method, and 1 point for the third. Overall, the results indicate that, while enterprises in the electronics and IT sector rely mainly on in-house development to obtain new technology, they also make use of a range of other methods to enhance their technology level.

Q12 : A similar scoring system to that used for Question 11 was used to determine the main sources of information on which enterprises in electronics and IT industry rely for technology innovation. The results showed that $31.5 \%$ of enterprises obtained information internally and from business partners, $7.0 \%$ obtained information from consumers, $6.5 \%$ obtained information from competitors, and $5.5 \%$ obtained information from trade shows, conferences and other events. In reality, the vast majority of enterprises make use of multiple channels to acquire information relating to innovation.

Q13: With regard to the problems affecting enterprises' innovation activity, overall, the most widely reported problem was manpower shortages (41.0\% of enterprises), followed by shortage of funds (21.5\%), insufficient information $(15.0 \%)$, and inadequate technical support (5.5\%). For the 28 enterprises located in the Hsinchu area, the main problem was shortage of funds $(32.1 \%)$, followed by manpower shortages $(28.6 \%)$, and insufficient information $(21.4 \%)$; it appears that companies in the Hsinchu area are less concerned about manpower issues, and more worried about funding, whereas in the Taipei metropolitan area and in Central/Southern Taiwan it is manpower shortages that are the key problem. It seems likely that the Hsinchu Science Park is still considered a prestigious place to work, both by graduates of 
neighboring universities and those of universities in other parts of Taiwan.

Q14: As to what enterprises in the electronics and IT industry considered to be their main sources of competitiveness, for $47.5 \%$ it was product quality, for $21.0 \%$ it was price, for $14.0 \%$ it was technology, and for $9.5 \%$ it was marketing capability (these figures were calculated using the same type of points system as outlined above) ; after-sales service was in fifth place. It can thus be seen that the companies that make up Taiwan's electronics and IT industry clusters are not only concerned with price competitiveness; product quality is actually their prime consideration.

\subsection{Network Building}

Q15 : Regarding their level of satisfaction with the business environment, enterprises were asked about their satisfaction with 14 individual items, including purchasing, transportation, collaboration with universities, accounting, taxation, technology exchange, etc. In most cases, the level of satisfaction given was "fairly satisfied" ; items for which a relatively high level of satisfaction was reported included "development of new technologies, new products and new businesses," for which $54.5 \%$ of respondents reported themselves to be "very satisfied," "access to product and market information" (50.8\%), and "ability to retain human talent" (46.6\%). Areas where more than $30 \%$ of enterprises stated that they were "dissatisfied" or "highly dissatisfied" included "government assistance" (39.3\%) and "support from universities and research institutes" (32.3\%). 10.2\% of enterprises reported that they were "highly dissatisfied" with the support that they received from financial institutions; this was a higher percentage than for any other item.

Q16: The question regarding enterprises' main collaborative partners divided collaboration into three categories: collaboration on technology development, collaboration on the commercialization of new technology, and collaboration on marketing and sales. With respect to collaboration on technology development, the main collaborative partner for enterprises in the electronics and IT industry is universities and public research institutes (49.5\% of enterprises), followed by cross-industry exchange $(35.5 \%)$, and collaboration with key suppliers $(31.5 \%)$. As regards commercialization of new technologies, enterprises' main collaborative partners include financial institutions (37.5\%), accounting firms and other service providers $(35.5 \%)$, industry associations $(34.0 \%)$, and other companies in the same industry $(31.5 \%)$. With respect to marketing and sales, enterprises' main partners include key customers $(56.0 \%)$, accounting firms and other service providers $(35.5 \%)$, other companies in the same industry (33.5\%), and other companies in other industries $(30.0 \%)$. Overall, "horizontal" collaboration between enterprises appears to be very common, reflecting the significance of the industry cluster effect. The importance attached to partnerships with financial institutions, consulting firms etc. in the area of marketing and sales is indicative of smaller or more recently established enterprises' need for external support (Figure 2).

Q17 : Regarding the areas with which respondents hoped to strengthen their collaboration with their main collaborative partners in the future, as with Question 16, collabora- 


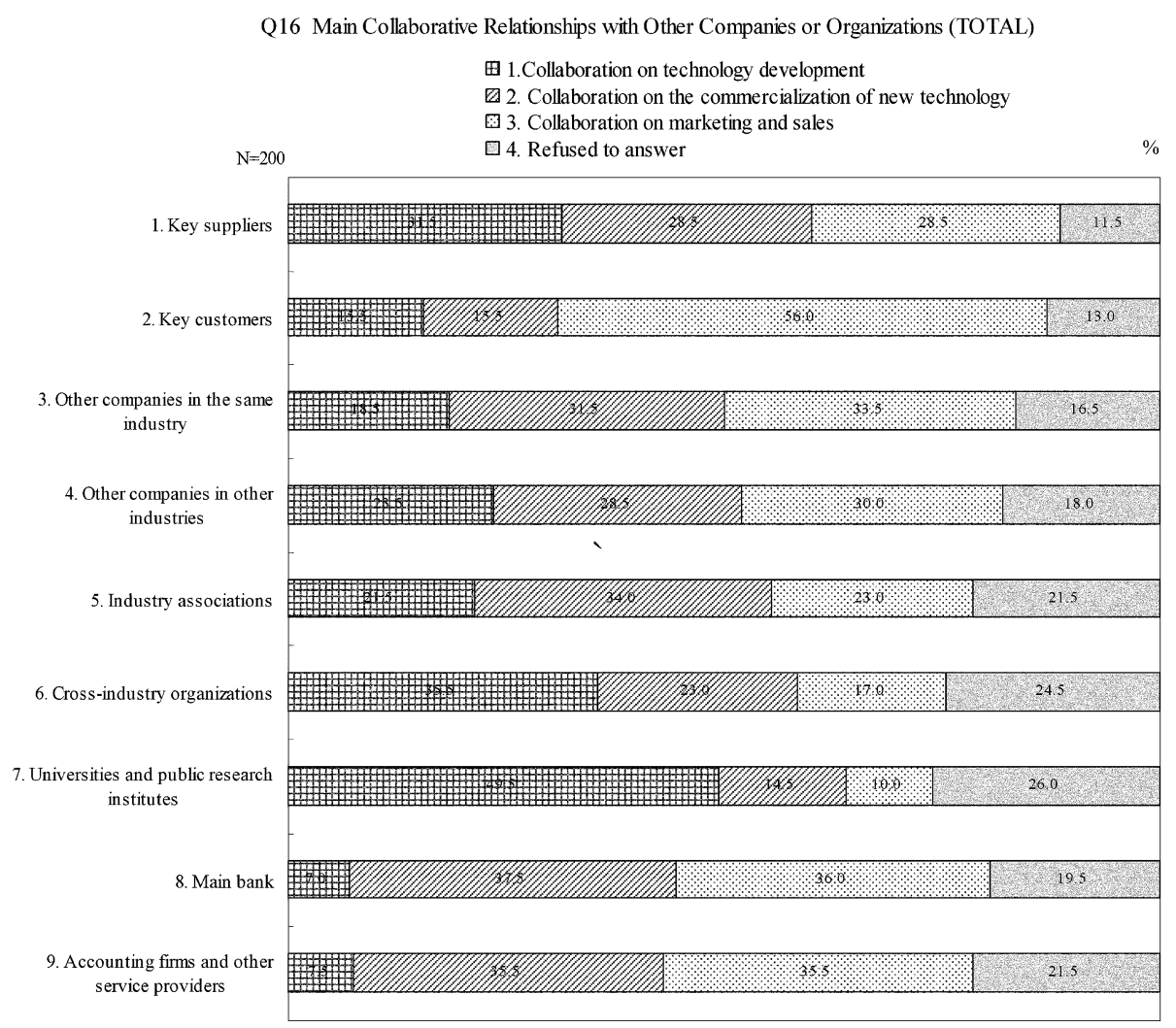

Figure 2. Collaborative Partners Source: Same as Table 3.

tion was divided into three categories: collaboration on technology development, collaboration on the commercialization of new technology, and collaboration on marketing and sales. With respect to collaboration on technology development, the main areas where enterprises hoped to strengthen collaboration included cooperation with universities and public research institutes (48.5\% of respondents), followed by cross-industry exchange (36.5\%), and cooperation with key suppliers $(36.0 \%)$. As regards collaboration on the commercialization of new technology, the main categories of partner with which firms anticipated increased collaboration in the future included financial institutions $(38.0 \%)$, accounting firms and other service providers $(37.0 \%)$, industry associations $(31.0 \%)$, and other firms in the same industry $(30.0 \%)$. With respect to collaboration on marketing and sales, the main categories of partner for future collaboration are key marketing targets $(47.0 \%)$, accounting firms and other service providers $(32.0 \%)$, university alumni association and other organizations (30.5\%).

For enterprises located in the Hsinchu area, the main future partners for collaboration on technology development will be universities and private research institutes $(57.6 \%) ; 63.6 \%$ of enterprises were interested in collaborating with new partners in the university sector. These data conform to the characteristics of the hi-tech 
cluster in the Hsinchu area.

Q18: As regards the distance between respondents and their key collaborative partners, in most cases the car journey required was between 30 and 60 minutes; this was true for industry association offices, key suppliers, universities and public research institutes. The main exceptions were financial institutions, which, in $44.5 \%$ of cases, were located within 10-30 minutes' drive, and key customers, which, in $43 \%$ of cases, were located over 2 hours away. Overall, the results showed that enterprises in the electronics and IT sector have their most frequent day-to-day contacts with financial institutions, and that these are also their geographically closest partners. Enterprises are not really in a position to control where there customers are located. As might be expected, the average distance between enterprises and their industry association, key supplier, university and research institute partners falls between these two extremes.

Q19: With regard to the methods whereby firms in the electronics and IT industry communicate with their collaborative partners, in most cases firms rely mainly on the telephone, fax and e-mail. However, in $48.0 \%$ of cases transactions with financial institutions are conducted in person, and a high percentage of transactions with accounting firms and other service providers are also conducted in person.

Q20 : As regards the frequency of direct, person-to-person contact with partners, contact that takes place on a weekly basis or more frequently was reported most often with respect to financial institutions $(58.0 \%$ of firms), followed by key customers $(54.0 \%)$, and key suppliers $(50.5 \%)$. Contact with other companies in different industries or in the same industry, and with service providers, tended to be on a roughly monthly basis, while face-to-face contact with industry associations and with universities and public research institutes was usually undertaken once every three to four months.

Q21 : Regarding the areas in which enterprises felt that the business environment in their region needed to be improved, the share of firms that felt that tax breaks and a more relaxed regulatory framework were either necessary or absolutely necessary was $57 \%$; $40.5 \%$ reported having no need for business support ; $37.5 \%$ stated that they had no need for accounting and other services. It is worth nothing that this question was applicable mainly to those companies located in the Hsinchu Science Park; companies not located in the Park would of course not have any need for the banking and accounting services available in the Park, so the companies reported no need for such services would mainly be firms located in areas other than Hsinchu. This problem derived from the fact that, initially, it was intended that this question would be directed only at firms located in the Hsinchu Science Park; in the event, the number of valid questionnaires returned from firms located in the Park was not sufficiently large, so companies located in other areas were also included. This is why the results obtained in this question appear to contradict those from other questions (Figure 3). 


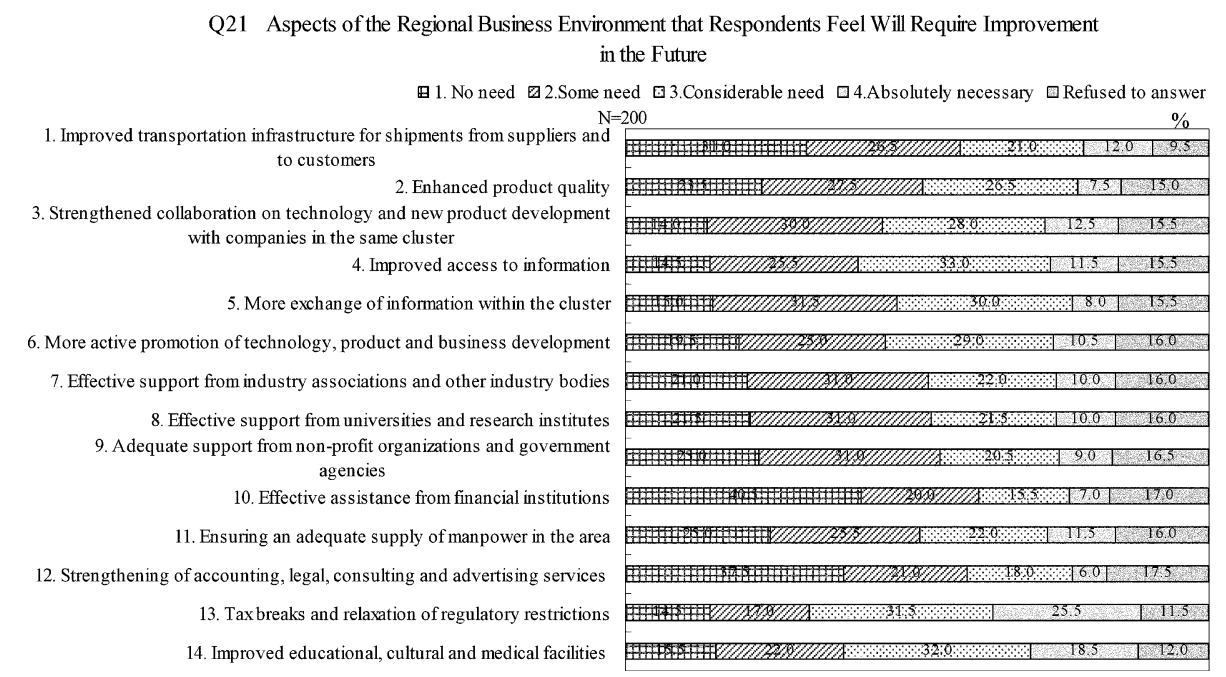

Figure 3. Aspects of the Business Environment that Respondents Feel Need to be Improved in the Future

Source: Same as Table 3.

\section{Statistical Analysis of the Questionnaire Survey Results}

Besides analyzing the results obtained for each of the 21 individual questions used in the questionnaire survey, we also made use of the multivariable Probit Model to examine the questions of whether the industry cluster effect helped to boost productivity, and whether industry cluster development was conducive to technology innovation. As the number of valid questionnaires returned from firms in the Hsinchu Science Park was too low (28 firms), the statistical analysis was performed with respect to Northern Taiwan as a whole, treating the entire region as a single hi-tech sector cluster. The following estimation formula was used :

Productivity indicator $=\mathrm{C}_{1}+\beta_{1}$ (basic enterprise attribute variables) $+\mathrm{r}_{1}$ (industry cluster pointer variable)

Technology innovation $=\mathrm{C}_{1}+\beta_{1}$ (basic enterprise attribute variables) $+\mathrm{r}_{2}$ (industry cluster pointer variable)

Dependent variables :

1. Corporate earnings (Q9) are used to measure enterprise productivity. If a firm has made a profit for two consecutive years, it is awarded a score of 2 ; if it has made a profit for only one of the two years, it is awarded a score of 1 ; if it has not made a profit in either year, it is awarded a score of 0 .

2. Data on technology innovation $(\mathrm{Q} 10)$ are used to measure enterprise innovation capability. If a firm has frequently engaged in product innovation, process innovation, management innovation or the acquisition of intellectual property, it is awarded a score of 2 ; if it has engaged in such activity on an occasional basis, it is awarded a score of 1 ; if it has not engaged in such activity, it is awarded a score of 0 . 
Independent variables :

1. Basic enterprise attribute variables: (1) Year of establishment. (2) If the enterprise chairman/president holds a bachelor's degree or higher from a foreign university, then a score of 1 is given; if not, then a score of 0 is given. (3) If the enterprise is located within an industry cluster, then a score of 1 is given; if not, then a score of 0 is given. (4) Average capitalization per employee. (5) Foreign ownership ratio.

2. Industry cluster variables: Distance between the enterprise and its main partners companies within the cluster, communication methods, and frequency of communication.

(1) Distance variable: Within 10 minutes -4 points; within 30 minutes -3 points ; within 1 hour- 2 points; within 2 hours- 1 point ; over 2 hours -0 points.

(2) Communication method variable: Face-to-face contact-3 points; telephone/ fax-2 points; e-mail-1; none-0 points.

(3) Communication frequency variable: Every week -5 points ; every two weeks -4 points; once a month-3 points; once every two months -1 point; never-0 points.

Based on the estimation results, the following conclusions were reached (Table 4) :

1. The shorter the length of time than an enterprise has been in existence, the more likely it is to have been making a loss ; however, younger enterprises tend to more active in terms of innovation.

2. Having a chairman/president who studied at an overseas university does not appear to help firms achieve superior earnings performance; however, it does lead firms to be more active in terms of innovation.

3. Judging from the data for the 28 respondents located in the Hsinchu area, there does not appear to be a significant correlation between being part of an industry cluster and achieving superior operational performance ; however, if the whole of Northern Taiwan (Hsinchu and all areas to the north) is treated as a single large industry cluster, then being part of a cluster does seem to be correlated with superior earnings performance.

4. A higher ratio of foreign ownership is associated with higher earnings, and also with a higher level of innovation activity.

5. With regard to the industry cluster pointer variables, with the exception of industry associations and service providers (such as accounting firms), proximity to partners appears to help enterprises to achieve superior earnings performance and encourages them to be more active in terms of innovation. These results suggest that the industry cluster effect does have a significant impact.

\section{Conclusions}

Like many other countries, Taiwan has experienced its own "economic miracle." Up until the 1980s, the term "economic miracle" as applied to Taiwan basically referred to Taiwan's success in achieving high export growth; however, from the 1980s on, the growing 
Table 4. Results of Statistical Data Analysis with Respect to Industry Clusters in Northern Taiwan

\begin{tabular}{|c|c|c|c|c|c|}
\hline Dependent Variable & Earnings & $\begin{array}{l}\text { Product } \\
\text { Innovation }\end{array}$ & $\begin{array}{l}\text { Process } \\
\text { Innovation }\end{array}$ & $\begin{array}{l}\text { Management } \\
\text { Innovation }\end{array}$ & $\begin{array}{l}\text { Intellectual } \\
\text { Property } \\
\text { Acquisition }\end{array}$ \\
\hline Year of establishment & $-0.024^{* *}$ & $0.027^{* * *}$ & & $0.013^{*}$ & $0.018^{* *}$ \\
\hline CEO's educational attainment & $-0.74 * * *$ & $0.74^{* * *}$ & & $0.50^{*}$ & \\
\hline Enterprise location & $0.45^{* *}$ & & & & \\
\hline Foreign ownership ratio & $1.98^{* *}$ & & & & $0.99^{* *}$ \\
\hline Distance from main supplier & & $0.34^{* * *}$ & $0.17^{*}$ & & \\
\hline $\begin{array}{l}\text { Distance from partner companies in } \\
\text { other industries (excluding suppliers } \\
\text { and customers) }\end{array}$ & & & $0.29 *$ & & $0.40^{* *}$ \\
\hline $\begin{array}{l}\text { Distance from industry associations } \\
\text { etc. }\end{array}$ & & & & $-0.29 * *$ & \\
\hline Distance from main bank & $0.30 * *$ & & & & \\
\hline $\begin{array}{l}\text { Distance from accounting firms and } \\
\text { other service providers }\end{array}$ & $-0.32 * *$ & & & & \\
\hline $\begin{array}{l}\text { Main method of communication with } \\
\text { suppliers }\end{array}$ & & $-0.28^{*}$ & & & \\
\hline $\begin{array}{l}\text { Main method of communication with } \\
\text { customers }\end{array}$ & $-0.30^{*}$ & $-0.27^{*}$ & & & \\
\hline $\begin{array}{l}\text { Main method of communication with } \\
\text { universities and public research insti- } \\
\text { tutes }\end{array}$ & & & & & $0.39 * *$ \\
\hline $\begin{array}{l}\text { Main method of communication with } \\
\text { accounting firms and other service } \\
\text { providers }\end{array}$ & & & $-0.24^{*}$ & & $-0.27^{*}$ \\
\hline $\begin{array}{l}\text { Frequency of communication with } \\
\text { other companies in the same industry } \\
\text { (excluding suppliers and customers) }\end{array}$ & & & & $0.22 * *$ & \\
\hline $\begin{array}{l}\text { Frequency of communication with } \\
\text { industry associations }\end{array}$ & & & & $-0.23^{* *}$ & \\
\hline $\begin{array}{l}\text { Frequency of communication with } \\
\text { industry associations, etc. }\end{array}$ & $-0.34^{* *}$ & & & & \\
\hline $\begin{array}{l}\text { Frequency of communication with } \\
\text { universities and public research insti- } \\
\text { tutes }\end{array}$ & & & & $0.25^{* *}$ & \\
\hline
\end{tabular}

Note: ${ }^{* *}$ denotes a level of significance of $0.01, * *$ denotes a level of significance of 0.05 , and *denotes a level of significance of 0.10 .

Source: Same as Table 3.

importance of the hi-tech sector within the economy gave Taiwan's economic miracle a character significantly different from that of most other nations. The key element in this successful transformation of the Taiwanese economy was the electronics and IT industry. The IT and Electronics Industry Yearbook defines the electronics and IT industry as including the IT hardware industry, the information services industry, the wireless communications industry, the electronic components industry, the precision instruments industry, 
optoelectronics, multimedia, display manufacturing, semiconductors, fax machine manufacturing and consumer electronics. The growth of the semiconductor industry has been particularly impressive; the provision of extensive funding, tax incentive and infrastructure support by the government was supported by the cluster effect deriving from the establishment of the Hsinchu Science-based Industrial Park in 1980, which helped the semiconductor industry to grow and innovate, and facilitated technology diffusion. Today, the whole of Northern Taiwan constitutes a single large hi-tech industry cluster, extending from Nangang and the Neihu Technology Park in the north down through the Dingpu Science Park in Tucheng and the Hwaya Industrial Park in Taoyuan County to the Hsinchu Science Park and the Chunan Branch of the Hsinchu Science Park. Adding in the Central Science Park and the Tainan Science Park in southern Taiwan, Taiwan can fairly be said to have developed into a real "Technology Island."

As regards the key factors behind the successful development of Taiwan's electronics and IT industry, the results obtained in the questionnaire survey implemented as part of the international comparison of industry cluster development in Japan, Taiwan and South Korea undertaken jointly by Nagoya University, the Chung-Hua Institution for Economic Research, and National Taiwan University point to the importance of the close integration of the up-, mid- and downstream segments within the semiconductor industry (and within the hi-tech sector as a whole). Besides its tight vertical integration, the industry is also characterized by an ability to respond flexibly to changes in market demand, having successfully made the transition from original equipment manufacturing (OEM) to original design manufacturing (ODM) and then to branded manufacturing. Most important of all is the close integration with the global supply chain, although the role played by the Chinese entrepreneurial spirit should not be overlooked. In addition, the Taiwanese electronics and IT industry has displayed an impressive ability to cultivate human talent; the existence of a high-quality labor force has contributed to the industry's strong $R \& D$ and innovation capabilities, which have supported the growth of the electronics and IT industry cluster in Northern Taiwan. Industry cluster development is of course closely linked to economies of scale, with the positive externalities that economies of scale create helping to attract new investment. Past studies have shown that strong innovation capability is associated with geographical concentration; the development of Taiwan's semiconductor industry certainly appears to fit this pattern. Geographical proximity is very much conducive to technology innovation; the exchange of knowledge between firms in different segments of the semiconductor industry (including IC design, IC foundry operation, testing and assembly) that are located close to one another has helped to create a highly efficient manufacturing model. The remarkably high innovation capabilities displayed by Taiwanese IC design firms are attributable mainly to the fact that these firms are working for themselves, not for other companies. This situation is reflected in the survey results, which show a particularly high level of innovation activity among firms located in the Hsinchu area.

Links with Silicon Valley in the U.S. have played an important role in the growth of Taiwan's hi-tech sector. However, the most important factor has been the support that the Taiwanese government has provided to strengthen the integration of the up-and downstream segments of the industry, for example by assisting with technology transfer and promoting 
new business start-up. Policy support from the government-e.g. commissioning privatesector companies to assist with the implementation of large-scale government projects, or the spinning off of public-sector pilot production facilities to create UMC and TSMC-has undoubtedly been a key factor in the successful development of hi-tech industry clusters in Taiwan.

The economic development that Taiwan will be adopting in the future will see a shift away from labor-intensive, capital-intensive, environmentally-degrading production towards resource integration and high value-added. The achievement of this goal will require effective coordination of local, regional and national resources and the establishment of new mechanisms for collaboration between industry, universities and research institutes so as to stimulate industry cluster development ; the strengthening of collaboration between industry and academia is of particular importance in this respect. The results obtained in this questionnaire survey are testimony to the success of electronics and IT industry cluster development in Taiwan.

\section{References}

[1] Acs, Z.D., D.B. Audretsch and M. Feldman, "Real Effects of Academic Research: Comment," AER, 82 (1), 1992, pp. 363-367.

[ 2 ] Acs, Z.D., D.B. Audretsch and M. Feldman, "R\&D Spillovers and Recipient Firm Size," Review of Economics and Statistics, 100 (2), May 1994.

[ 3 ] Audretsch, D.B. and M. Feldman, "R\&D Spillovers and the Geography of Innovation and Productivity," AER, 86, 1996, pp. 630-640.

[4] Bresnathan, T., A. Gambardella and A. Saxenian, "Old Economy' Inputs for 'New Economy' Outcomes: cluster Formation in the New Silicon Valleys," Industrial and Corporate Change, Vol. 10, No. 4, 2001, pp. 835-860.

[5] CIER, "The Strategy to Attract High-Tech business and Amendments to the statute of ScienceBased Industrial park," Mimeograph Unpublished Project Report, CIER, 1990.

[6] Jacobs, J., The Economy of Cities, New York: Vintage, 1969.

[ 7 ] Jaffe, A.B., "Real Effects of Academic Research", AER, 79(5), 1989, pp. 957-970.

[8 ] Lucas, Robert E.B., "Demand for India's Manufactural Exports," Journal of Development Economics, 29(1), 1998, pp. 63-75.

[9] Porter, M.E., The Competitive Advantage of Nations, New York: Macmillan, 1990.

[10] Chen, Tain-Jy, "The Emergence of Hsinchu Science Park as an IT Cluster", Growing Industrial Clusters in Asia, The World Bank, 2008. 